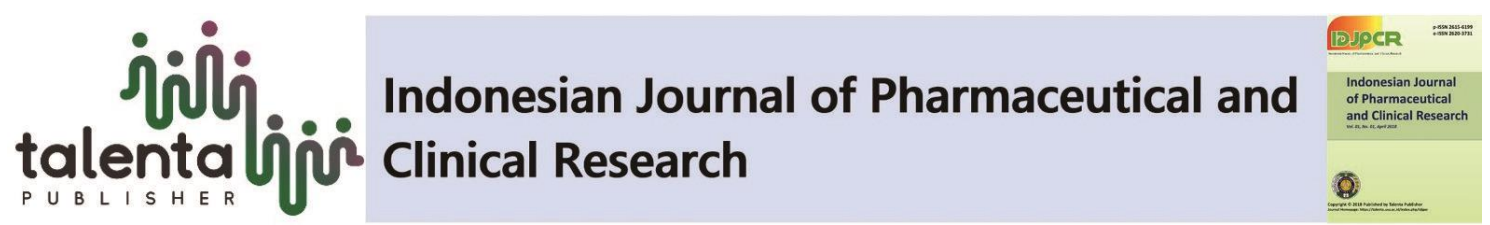

\title{
Evaluation of Drug Management of Pharmacy Installation at Universitas Sumatera Utara Hospital
}

\author{
Syilvi Rinda Sari, Khairunnisa", Aminah Dalimunthe
}

Departement of Pharmacology, Faculty of Pharmacy, Universitas Sumatera Utara

\begin{abstract}
Drug management is an important aspect for health services in hospital. Pharmacy Installation in hospital responsible in running drug management in hospital, including selection, planning, procurement, and distribution of the drugs. Poor management will cause inadequate health services, moreover hospital loss. The aim of this research was to evaluate drug management system of Pharmacy Installation in Universitas Sumatera Utara Hospital. It is a descriptive-evaluative research, and the data for this research was collected retrospectively and concurrently. This research used a indicator to analyze the data and comparing those data with the standard. The result of this research showed that there was $93.8 \%$ drug selection in hospital suitable with National Formulary. In, this research showed that the drug planning and procurement frequency of each drug item per year were categorized as low with less than 12 times in a year. Then, this research showed that Pharmacy Installation in the hospital distributed the drugs precisely with $100 \%$ accuracy in terms of drugs amount in stock cards and shed management system. Further, it was also known that the percentage of expired and broken drugs was below $0.05 \%$, while the percentage of dead stock was $100 \%$, and the level of drugs availability period was for 17 month 16 days. In conclusion, this research showed that drug management system of Pharmacy Installation in Universitas Sumatera Utara Hospital was accordance to the standard.
\end{abstract}

Keyword: Evaluation, Management, Drug, Pharmacy Installation

\begin{abstract}
Abstrak. Manajemen obat merupakan aspek penting bagi pelayanan kesehatan di rumah sakit. Manajemen obat di rumah sakit dilakukan mulai dari tahap seleksi, perencanaan, pengadaan dan distribusi obat yang merupakan tanggung jawab dari instalasi farmasi rumah sakit. Manajemen obat yang tidak baik akan menyebabkan pelayanan kesehatan yang tidak berjalan dengan lancar sehingga mengakibatkan kerugian bagi rumah sakit. Tujuan dari penelitian ini adalah untuk mengevaluasi sistem manjemen obat yang dilakukan di instalasi farmasi Rumah Sakit Universitas Sumatera Utara. Penelitian ini bersifat deskriptif-evaluatif dengan pengambilan data secara retrospektif dan concurrent. Data yang diperoleh dianalisis menggunakan indikator dan dibandingkan dengan standar yang telah ditetapkan. Hasil penelitian menunjukkan bahwa pada tahap seleksi 93,8\% obat-obatan yang disediakan di rumah sakit sesuai dengan Formularium Nasional. Pada tahap perencanaan dan pengadaan diketahui bahwa frekuensi tiap item obat per tahun termasuk kategori rendah yaitu $\leq 12 x /$ tahun. Manajemen obat pada tahap distribusi diketahui bahwa ketepatan jumlah obat pada kartu stok sebesar 100\%, sistem penataan
\end{abstract}

${ }^{*}$ Corresponding author at: Departement of Pharmacology, Faculty of Pharmacy, Universitas Sumatera Utara

E-mail address: khairunnisa7@usu.ac.id 
gudang $100 \%$, persentase dan nilai obat yang kadaluarsa dan atau rusak $\leq 0,05 \%$, persentase stok mati $100 \%$, dan tingkat ketersediaan obat 17 bulan 16 hari.

Kata kunci: Evaluasi, Manajemen, Obat, Instalasi Farmasi

Received 3 September 2020 | Revised 10 December 2020| Accepted 20 December 2020

\section{Introduction}

Drug management is an important aspect to improve the quality of pharmaceutical cares in hospital [1]. Pharmaceutical cares in hospital including standard management of pharmaceutical supplies, medical devices, disposable medical materials, and clinical pharmacy services. Pharmaceutical service is aimed to identify, prevent, and solve drugs related problems [2].

Universitas Sumatera Utara Hospital is categorized as type C hospital in Indonesia. It was known from interview with informant at Pharmacy Installation in that hospital, there was no previous evaluation about drug management there.

Drug management in hospital has several steps that related one to each other; those are selection, planning, procurement, and distribution steps. Fair coordination between each steps will ensure the system run optimally. Poor coordination among those will cause inefficiency of supply system and the usage of available drugs [3].

Inefficient of drug management will cost the hospital. It was mentioned in previous researches from various researchers, such as Fakhriadi Akhmad et.al [4] in their research, they tried to analyze the efficiency of drug management at Pharmacy Installation in PKU Muhammadiyah Temanggung Hospital. The result of this research told that the drug management in that hospital was simply inefficient. Then, similar research that conducted by Wati et.al [5] in different setting also mentioned that drug management was not suited the standard requirement. Next, it was known from the research by Romero [6] that started from drug acceptance in shed until distribution into hospitals, there was any sector that caused inefficiency. Those sectors such as; improper inventory management, prolong inventory administration cycle, and long process on recalling products due to any errors.

Therefore, it was considered to conduct an evaluation to drug management to identify the problems and weaknesses of the system. By knowing those, it was believed that any improvement could be done to improve health services for community.

\section{Methods}

This was a descriptive evaluative research. The procedure of this research was to evaluate the management of drugs including selection process, planning, procurement, and distribution. The data was collected concurrently and retrospectively. Data collection was conducted by several 
methods. First, this research collected the data by direct observing to accuracy indicator of drug amount in stock cards, shed management system, expired stock percentage. Then, it was collected by doing interview to related sectors in drug management at Pharmacy Installation in Universitas Sumatera Utara Hospital. Lastly, to assess the indicator of suitability of drug items available with the National Formulary, the frequency of yearly drugs procurement, the percentage of expired and/or damaged drugs, and drugs availability level, this research collected the data from documents in 2017 and 2018.

This research used the standards that have been created by Health Department of Republic Indonesia in the Supervision and Evaluation for Public Drugs and Medical Supplies Guidelines [1], Decree of the Republic Indonesia's Director General of Health Services Ministry of Health [2], Pudjaningsih [7], Quick [3] and WHO [8].

\section{Results and Discussion}

\subsection{Selection}

The purpose of available drug items suitability with National Formulary indicator was to identify the level of drug usage against National Formulary. To identify the percentage of this indicator, this research compared the amount of drug items in Hospital Formulary to drug items that suited to National Formulary are shown in Table 1.

Table 1. Suitability of available drug items in hospital with National Formulary

\begin{tabular}{lcc}
\hline \multicolumn{1}{c}{ Description } & Item & Standard \\
\hline $\begin{array}{l}\text { Number of drug items that suited } \\
\text { to National Formulary }\end{array}$ & 846 & - \\
\hline $\begin{array}{l}\text { Number of drug items in } \\
\text { Formulary of Universitas }\end{array}$ & 901 & - \\
Sumatera Utara Hospital & & \\
\hline $\begin{array}{l}\text { Suitability available drug items to } \\
\text { National Formulary (\%) }\end{array}$ & $93.8 \%$ & $\geq 80 \%$ \\
\end{tabular}

Based on Table 1, it showed that suitability of available drug items in hospital to National Formulary was meet the standard requirement, with $93.8 \%$. Based on that result, it means that drugs given to patients in the hospital was mostly suited to drug items in National Formulary.

\subsection{Procurement}

Drug procurement frequency is the summed of each drug items in a year. The value of each rug item procurement was collected from retrospective data collection. The source of the data was from drug procurement documents by counting procurement frequency of each drug items in a 
year 2018. There were 452 drug items was used as the sample in this research to identify procurement frequency of each drug items per year.

Table 2. Procurement frequency of each drug items per year

\begin{tabular}{lc}
\hline Procurement Frequency & Total Drugs \\
One time & 81 \\
Two times & 69 \\
Three times & 58 \\
Four times & 58 \\
Five times & 71 \\
Six times & 53 \\
Seven times & 32 \\
Eight times & 20 \\
Nine times & 6 \\
Ten times & 2 \\
Eleven times & 2 \\
\hline
\end{tabular}

Table 2 showed that the highest procurement frequency in 2018 at Pharmacy Installation atUniversitas Sumatera Utara Hospital was 11 times, and the lowest was only once a year. Based on the standard of procurement frequency, it was categorized as low if the frequency was low as 12 times a year. Furthermore, it was considered as medium and high if the procurement frequency was 12-24 times and more than 24 times a year respectively [7].

It can be said that procurement frequency of each drug items at Universitas Sumatera Utara hospital was labelled as low with procurement frequency was less than 12 times a year. From the interviewed with related sectors in Pharmacy Installation at the hospital, this low procurement frequency was due to long and complicated procurement procedures that consumed much time.

\subsection{Distribution}

One of the main task in pharmaceutical cares at hospital is drug distribution. Distribution step in drug management plays important roles, such as pharmaceutical drugs and medical devices delivery to destination unit in hospital, including to the patient [9]. Insufficient drug distribution caused the decreased of drugs availability level. In contrast, not only caused an emptiness in drug shed, but also it will cause high number of unused accumulated drugs that will lead the drugs into expired or unusable. This condition will affect the current budget for drugs management [10].

In this research, the number of drugs suitability in stock card, shed management system, the percentage of expired drugs, percentage of dead stock, and drugs availability level were used as 
indicators for distribution steps. The result of this research against the indicator in distribution steps as mentioned below:

Table 3. The Result of Distribution Indicator

\begin{tabular}{clcc}
\hline No. & \multicolumn{1}{c}{ Indicator } & Standard & Result \\
1. & $\begin{array}{l}\text { Suitability of drugs amount in stock } \\
\text { card }\end{array}$ & $100 \%$ & $100 \%$ \\
2. & Shed management system & $100 \%$ & $100 \%$ \\
3. & $\begin{array}{l}\text { Percentage of expired or damaged } \\
\text { drugs }\end{array}$ & $\leq 0.2 \%$ & $0.05 \%$ \\
4. & Percentage of dead stock & $0 \%$ & $0 \%$ \\
5. & Drugs availability level & $\begin{array}{c}12-18 \\
\text { months }\end{array}$ & $\begin{array}{c}17.56 \text { months } / 17 \\
\text { months 16 days }\end{array}$ \\
\hline
\end{tabular}

From Table 3 above, it showed that drug distribution in Pharmacy Installation at Universitas Sumatera Utara Hospital had met the minimum standard. Therefore, it can be said that drug distribution system in the Hospital was proper and suited to the standard.

\section{Conclusion}

In conclusion, drugs management in Pharmacy Installation at Universitas Sumatera Utara Hospital that consist of selection, planning, procurement, and distribution steps was categorized as well managed by this research.

\section{REFERENCES}

[1] Department of Health, Guidelines for the Supervision and Evaluation of Public Drugs and Supplies. Republic of Indonesia: The Department of Health, pp. 8-15. 2008.

[2] Ministry of Health of Indonesia. Regulation of the Minister of Health of the Indonesia No. 72 About The Standard of Pharmaceutical Services In The Hospital. Jakarta. 2016.

[3] J. D. Quick, "Managing Drug Supply, 2nd Ed," Kumarian Press. USA, p. 117. 1997.

[4] A. Fakhriadi, Marchaban, and D. Pudjaningsih, "Analysis of Drug Management in Pharmacy Installation at PKU Muhammadiyah Temanggung Hospital period 2006, 2007, and 2008," Journal of Management and Pharmaceutical Services, vol. 1, no. 2, pp. 94102. 2011.

[5] W. Wati, A. Fudholi, and G. P. Widodo, "Evaluation of Drug Management and Improvement Strategy with the Hanlon Method in Pharmacy Installation at Karel Satsuitubun Hospital District Southeast Maluku Period 2012," Journal of Management and Pharmaceutical Services, vol. 3, no. 4, pp. 283-289. 2013.

[6] A. Romero, "Managing Medicines In The Hospital Pharmacy: Logistics Inefficiencies," in Proceedings of the World Congress on Engineering and Computer Science, San Francisco, October 23-25. 2013.

[7] D. Pudjaningsih, "Development of Drug Management Efficiency Indicators in Pharmacy Installation Hospital. Yogyakarta.1996.

[8] World Health Organization, How to Investigate Drug Use in Health Facilities, Selected Drugh Use Indicator, Action Program Essential Drug, p. 46 - 52. 1993.

[9] M. F. Satrianegara, E. Bujawati, dan Guswani, "Analysis of Drug Logistic Management in Pharmacy Installation at RSUD Lanto Daeng Pasewang District Jeneponto," Al-Sihah : Public Health Science Journal, vol. 10, no. 1, pp. 37-47. 2018. 
[10] G. E. Pramukantoro and Sunarti, "Evaluation of Drug Management in Pharmacy Installation at Surakarta Health Office 2015," Indonesian Pharmacy Journal, vol 1, no. 1, pp. 50-59. 2018.

[11] Ministry of Health of Indonesia. Decree of The Director General of Health Services No. HK.02.03/I/2630/2016. Jakarta, pp. 48. 2016. 